\title{
Effect of Pre and Post Emergence Herbicides on Weeds and Productivity of Aerobic Basmati Rice (Oryza Sativa L): A Review
}

\author{
Pradeep Rajput ${ }^{1}$, Adesh Singh ${ }^{1}$, Ravindra Kumar Rajput ${ }^{2}$, \\ Gaurav Shukla ${ }^{1}$ and Pravesh Kumar ${ }^{3}$
}

\author{
${ }^{1}$ Department of Agronomy, Sardar Vallabhbhai Patel University of Agriculture \& Technology, \\ Meerut, U.P., India \\ ${ }^{2}$ Department of Soil Science \& Agricultural Chemistry, Matter specialist (soil science), KVK \\ Mathura, U.P., India \\ ${ }^{3}$ Department of Soil Science \& Agricultural Chemistry, Sheila Dhar Institute of Soil Science, \\ University of Allahabad, Prayagraj, U.P., India
}

*Corresponding author

\section{A B S T R A C T}

Keywords

Dry direct-seeded rice, Herbicides, Weed management practices, Weed flora, Yield and Dry matter

Article Info

Accepted:

14 November 2020

Available Online:

10 December 2020
High labour cost, scarcity of labour during the critical period of weed competition, and unfavorable weather at weeding time. Under such situation, herbicides have been tremendous contributor to agriculture. Direct seeding of rice (DSR) refers to the process of establishing the crop from seeds sown in the field rather than by transplanting seedling from the nursery. Before the advent of Green revolution and adoption of irrigation, rainfed rice was often broadcasted into moist soil and yields were low, variable and highly prone to weed competition. Weed spectrum and degree of infestation in rice field are often determined by rice ecosystems and establishment methods. The reduction in yield due to weed infestation under DSR is reported up to $50-80 \%$ and it can be reached to $100 \%$ if weeds are not controlled throughout the season. The main weeds of rice field such as Echinochloa spp., E. colona, Dactyloctenium aegyptium, Leptochloa chinensis and Elusine indica in DSR. Direct sowing rice matures 7 to 10 days earlier than transplanted rice due to absence of transplanting shock; which hastens physiological maturity and reduces vulnerability to late-season drought.Application of penoxsulam $25 \mathrm{~g} / \mathrm{ha}$ as broad-spectrum, azimsulfuron + metsulfuron-methyl for Cyperus spp., pendimethalin at $1.25 \mathrm{~kg} / \mathrm{ha}$ for Echinochloa spp. were found suitable for chemical weed management. All these herbicide mixtures were superior to weedy control in reducing the weeds' density and dry weight.

\section{Introduction}

Rice (Oryza sativa L.) is the leading cereal of the world (Juraimi et al., 2013) and two third of the Asian peoples receive their daily calories from rice (Rahman and Masood,
2012). Rice is the hub of food security of the global population. At global level, rice is grown on an area of about 163.2 million ha with production and productivity of 751.9 million tons and productivity 4.60 tones $\mathrm{ha}^{-1}$, respectively. India ranks first in respect of 
area 43.20 million ha second in production of 110.20 million tones, after China, but the productivity of rice is very low only 2.60 tones ha $^{-1}$ (Anonymous, 2016). Uttar Pradesh in respect of area 5.29 million ha and production 11.94 million tone, but the productivity of rice is low only 2.12 tone/ha (Anonymous, 2017). Water and labour scarcity threaten the sustainability of the traditional rice production system in Asia. In South and Southeast Asia, the major rice establishment method is manual transplanting of seedlings into flooded soil.

Flooded transplanted rice has the advantage of controlling the first cohorts of weeds because of standing water, which is known to suppress the germination of weeds that need oxygen to germinate. Furthermore, transplanted rice seedlings are larger than newly emerged weed seedlings, thus increasing the degree of competitive size asymmetry in the crop weed community and benefitting the crop at the expense of weeds (Weiner et al., 2001). The population in India is increasing at an alarming rate and more water is required for urbanization, whereas water resources are being depleted. Rice consumes about $50 \%$ of the total available irrigation water (Gianessi and Williams, 2011). India, increased economic growth has increased the labour demand for nonagricultural sectors and reduced the availability of labour for agriculture. Direct seeding of rice establishment is spreading rapidly in India. Direct seeding rice serves several advantages i. e. saves labour, faster and easier planting helps in timely sowing, less drudgery, early crop maturity by $7-10$ days, less water requirement, high tolerance to water deficit, often high yield, low production cost and more profit, better soil physical condition for following crops and less methane emission (Balasubramanian and Hill, 2002). Labour scarcity and increasing labour costs weeding in rice under moist conditions is the last choice of agricultural labourers which has given momentum to the use of herbicides for weed management in rice. Direct seeded rice crop suffers from complex weed flora and several herbicides like pendimethalin and anilofos have been tested for this. These herbicides have differential effects on these weeds. That is why to control all types of weeds (grasses, sedges and broad-leaved weeds) strategy should be such that may provide broad spectrum weed control. In rice dry-seeded systems are subject to much higher weed pressure than transplanted rice because of dry ploughing and aerobic soil conditions. Yield loss in dry-seeded rice due to weeds is 27$80 \%$ in Pakistan (Awan et al., 2006; Khaliq et al., 2012) and 40-70\% in the Philippines (Phoung et al., 2005; Chauhan and Opena, 2013).

Proper weed management is considered one of the most important prerequisites in dry seeded rice systems to ensure high crop yield. High weed pressure in dry-seeded rice lowers the economic returns and, in extreme cases, it causes complete failure of the rice crop (Jabran et al., 2012). Hence, judicious weed management in dry-seeded rice is a critical factor for securing and sustaining food security in Asia's developing countries (Timsina and Connor, 2001). Chemical weed management is the most popular method of weed control in rice because it is cheaper, more reliable, and more labour- and timesaving than other weed control measures (Mazid et al., 2003). The use of herbicides in rice for controlling weeds has increased significantly over the last several years (FAO, 2002). This is because of increased labour wages, labour shortages, and a shift in rice planting method from transplanted to directseeded. For ecological weed management in dry-seeded rice, the use of herbicides is not ruled out, but they are used in combination with other weed management strategies. In 
Australia and Europe, herbicide use began with the introduction of direct-seeded rice (Bocchi et al., 2005; Taylor, 2007). In Asian countries, where direct seeding of rice is replacing transplanted rice, the use of herbicides has increased (Azmi et al., 2005; Rao et al., 2007; Weerakoon et al., 2011). Therefore, Indian farmers are shifting from puddled transplanted rice to dry-seeded rice.

\section{Dominant weed flora}

Weed flora in aerobic rice like grasses (Echinochloa crusgalli, E. colona, Dactyloctenium aegyptium, Leptochloa chinensis, Elusine indica), sedges (Cyperus rotundus, $C$. iria) and broad leaved (Trianthema portulacastrum, Ipomoea aquatic, Portulaca oleracea) species. Weed infestation is one of the major biotic constraints in rice production. Rice community is infested with diverse type of weed flora colonized by aquatic, semi-aquatic and terrestrial weeds, grown under diverse agro-climatic conditions, different cropping sequence, and tillage and irrigation regimes. About 350 species have been reported as weeds of rice, of which grasses are ranked as first posing serious problem followed by sedges and broad-leaf weeds causing major losses to rice production worldwide. The predominant weed associated with DSR in Asia has been presented (Table 1).

\section{Performance of rice different under establishment methods}

Rana et al., (2014) reported that Direct sowing rice matures 7 to 10 days earlier than transplanted rice due to absence of transplanting shock; which hastens physiological maturity and reduces vulnerability to late-season drought (Tuong et al., 2000). Awan et al., (2006) reported that Direct sowing rice was almost at par in yield with transplanted crop. Similarly, research study in Odisha in Cereal Systems Initiative in South Asia (CSISA) domain areas (20 locations in Bhadrak and Mayurbhanj districts in 2017-2018, unpublished) revealed that Direct sowing rice by seed cum- fertilizer drill produced the highest rice yield (5.29 t/ha) which was at par with manual random transplanting $(4.91 \mathrm{t} / \mathrm{ha})$ but significantly higher than manual broadcasted rice followed by beushening (4.24 t/ha) (Figure 1).

\section{Losses due to weeds}

Weeds in direct-seeded rice adversely affect yield, quality and cost of production as a result of competition for various growth factors. Extent of loss may vary depending upon cultural methods, rice cultivars, rice ecosystems, weed species association, their density and duration of competition. The greatest loss caused by the weeds, resulted from their competition with crop for growth factors, viz. nutrients, soil moisture, light, space, etc (Walia 2006). Trianthema monogyna was found to grow faster than other weeds during early stage due to shorter life cycle and contributed much more to the competition as compared to other weeds (Singh 2008). Yield losses are largely dependent on the season, weed density, weed species, rice cultivars, growth rate, management practices and rice ecosystem. Therefore, a systematic, efficient and effective weed management depends on timing and method of land preparation, effectiveness of herbicides, relative to the dominant weed species and soil conditions at the time of application, effect of weather on weeds and effect of combining herbicides and manual weed control. Water regimes in rice fields might determine the extent of yield loss due to weed competition. On average, estimated losses from weeds in rice are around $10 \%$ of total grain yield; however, can be in the range of 30 to $90 \%$, reduces grain quality and enhances the cost of production 
(Rao et al., 2007). In dry seeded aerobic rice, relative yield loss caused by weeds is as high as 50-91\% (Rao et al., 2007). Dhyani et al., 2010 recorded lowest density and dry weight of E.colona in TPR as compared to DSR. Season-long weed competition in directseeded aerobic rice may cause yield reduction up to $80 \%$ (Sunil et al., 2010). In extreme cases, weed infestation may cause complete failure of aerobic rice (Jayadeva et al., 2011). Thus direct-seeded aerobic rice is highly vulnerable to weeds compared with other rice ecosystems (Anwar et al., 2011). Weedy rice (Oryza sativa f. spontanea), also known as red rice, has emerged as a serious threat. It is highly competitive and causes severe rice yield losses ranging from $15 \%$ to $100 \%$ (Farooq et al., 2009). Weedy rice also reduces milling quality if it gets mixed with rice seeds during harvesting (Ottis et al., 2005).

\section{Shifting of weed flora}

Yield losses from weeds and the effectiveness of control measures depend largely upon the weed species present. Factors, which affect the composition of the weed flora, include landscape position, water control, soil fertility, season, rotations and herbicide use. Direct-seeding has replaced transplanting in Asia, the annual grasses Echinochloa colona and Leptochloa chinensis have succeeded the previously dominant Monochoria vaginalis and Ludwigia hyssopifolia (Ho and Itoh, 1991). Continuous use of herbicides for the control of annual grasses shifted the dominant species from grasses to broad-leaf weeds and sedges and from annuals to perennials. In India continuous use of grass killers such as butachlor in rice has resulted in a shift of weed flora to sedges as C. iria, Scripus spp., and Fimbristylis spp. (AICRPWC, 2002-03). Mortimer and Johnson (2008) during the study at Pantnagar confirmed that changing from transplanting to direct-seeding caused marked changes in the weed flora in the rice- wheat cropping system. With direct-seeding of rice there was a rapid increase in annual grasses, Echinocloa colona, E.crus-galli, Leptochloa chinensis: perennial sedge Cyperus rotundus and certain broad-leaf weeds such as Caesulia axillaris. Research on farmer's field showed that direct-seeding of rice is accompanied by a rapid shift in weed flora with an increase in abundance of E.colona, E. crusgalli, Ischaemum rugosum and Leptochloa chinensis and on more freely draining soil C.rotundus (Singh et al., 2006). Singh et al., (2013) reported that replacing transplanted rice to direct seeding rice resulted an increase in weed growth and also shift in the relative abundance of particular species. Direct seeded rice is accompanied by a rapid shift in weed flora with an increase in E.colona, E. crusgalli and Ischaemum rugosum.

\section{Principles of weed management}

The principles of weed control are the basis for the development of the various methods of weed control and management. There are a number of ways to control weeds. They are based on these principles.

Prevention

Control

Eradication

\section{Prevention}

Sowing of clean seed is perhaps the most important weed management technique in any crops. Rice seed contaminated with weeds is one of the major causes of weed infestation, especially in DSR. Rice seeds infested with weed seeds may introduce problematic weed species to a new field and increase the seed numbers in the soil weed seed bank. In many countries, for example, weedy rice or red rice spreads through the distribution of contaminated rice seeds to farmers and now 
this weed has become a menace because of the non availability of selective herbicides to control it. Mai et al., (1998) reported on average 466 weed seeds/kg rice seeds including 314 weedy rice seeds in Vietnam, which is 47 fold higher than permitted national purity level. In addition to clean crop seed, the machinery used for tillage, sowing, harvesting or threshing operations should also be cleaned before moving it from one field to another. Preventing weeds from entering an area may be easier than trying to control them once.

\section{Cultural control}

Cultural approaches play significant role to determine the competitiveness of a crop with weeds for above ground and below ground resources and hence might influence weed management (Grichar et al., 2004). Most cultural practices can be regarded as a means of weed suppression and an increase in their efficiency would contribute to better weed control. Moreover cultural control is also considered to be eco-friendly and when combined with herbicides or other methods can result in better weed management.

\section{Stale seed bed}

The stale seed bed technique is an important cultural practice that can be used before any crop to reduce the weed seed bank. In this technique, after pre-sowing irrigation, fields are left as such and weeds are allowed to germinate and thereafter are killed through cultivation or with the use of non-selective herbicide (e.g., paraquat or glyphosate) application or shallow tillage. This technique is quite effective in DSR, especially for controlling weeds such as C. rotundus, weedy rice, and volunteer rice seedlings. Herbicides may destroy weeds without disturbing the soil, which would be advantageous and hence reducing the possibilities of bringing new seeds to the upper soil surface. The rice seeds should be sown with minimum soil disturbance after destroying the emerged weeds. The use of zero- till-ferti-seed drills may be useful to serve this purpose. Singh et al., 2009 reported 53\% lower density in DryDSR after a stale seed bed than without this practice. Stale seedbed combined with herbicide (paraquat) and zero-till results in better weed control because of low seed dormancy of weeds and their inability to emerge from a depth $>1 \mathrm{~cm}$ (Chauhan and Johnson 2010). The success of stale seed bed de-pends on several factors: (a):- method of seed bed preparation (b):- method of killing emergence weed (c):- weed species (d):duration of stale seed bed and (e):environmental conditions.

\section{Brown manuring (Sesbania co-culture)}

"Brown manuring" practice involves seeding of rice and Sesbania crops together and killing the Sesbania crop 25-30 days after sowing (DAS) by application of 2,4- D-ester at 0.40$0.50 \mathrm{~kg} / \mathrm{ha}$. This will also help in meeting early $\mathrm{N}$ requirement of the crops and avoid early nitrogen and moisture stress (CIMMYT 2010, Gurjeet et al., 2013). Methane gas emission and global warming potential was maximum under conventional- TPR and emission of $\mathrm{N} 2 \mathrm{O}$ was maximum under DSR crop with conservation practice of brown manuring as the addition of organic matter to soil increased the decomposition rate, which resulted in higher emission of GHGs (Bhatia et al., 2011).

\section{Weed-competitive cultivar}

Rice cultivar with strong weed competitiveness is deemed to be a low- cost safe tool for weed management (Gibson and Fischer 2004). Short stature, early maturing, erect rice cultivars are less competitive with weeds than cultivars that are tall and have fast 
and vigorus early vegetative growth, a vigorus root system, high tillering and drooping leaves. It has been observed that early maturing rice cultivars and rice hybrids also have a smothering effect on weeds due to improved vigour and having the tendency of early canopy cover (Mahajan et al., 2011). Competitive rice cultivar effectively suppressed the infestation of Echinochloa spp. and helped reduce herbicide dependency (Gibson et al., 2001).

\section{Weed control approach}

Buhler (2002) says that prevention is the most basic of all weed control methods which restricts introduction and spread of weeds. Preventive measures include using weed-free seeds, maintaining clean fields, borders, and irrigation canals, and cleaning farm equipment. Rice seeds contaminated with weed seeds may introduce problematic weed species to a new field and enrich the soil weed seed bank. In addition to clean crop seed, the machinery used for tillage, sowing, harvesting, or threshing operations should also be cleaned before moving it from one field to another. Bunds and irrigation canals free from weeds may also help to reduce the spread of weed seeds through irrigation water.

\section{Physical approach}

Physical control of weeds is done manually or mechanically. Harrowing has been found effective in DSR, especially when the crop plants are larger than weeds. Hand weeding is very easy and environment-friendly but tedious and highly labor intensive and thus is not an economical for the farmers (Juraimi et al., 2013). Mechanical weeding using hand pushed weeders is feasible only where rice is planted in rows; however, weeds emerging within rows are difficult to remove with these weeders (Chauhan, 2012).

\section{Chemical approach}

High labour cost, scaricity of labour during the critical period of weed competition, and unfavorable weather at weeding time. Under such situation, herbicides have been tremendous contributor to agriculture. In large scale rice farming, herbicide based weed management has become the smartest and most viable option due to scarcity and high wages of labor (Anwar et al., 2012). Application of penoxsulam at 20,22.5 and 25 $\mathrm{g} /$ ha have better control over the density of grasses and broad-leaf weeds in DSR (Singh et al., 2012). Singh et al., (2010) found effective control over the density of $C$. rotundus with the application of azimsulfuron + Metsulfuron-methyl. Lowest population of E. colona was recorded with application of pendimethalin at $2.0 \mathrm{~kg}$ while of $\mathrm{C}$. axillaris was with combined application of bentazone with pendamethalin (Singh et al., 2005).And other chemicals are given in table 2 .

\section{Biological approach}

Using different herbivorous bio-agents such as fish, tadpoles, shrimps ducks and pigs are used to control weeds in irrigated lowland rice in a few countries but these cannot be used in aerobic rice, where there is no standing water. Weed control by mycoherbicides are now being studied to reduce herbicide dependency. The most promising fungi for biocontrol of barnyardgrass are Exserohilum monocerus and Cocholiobolus lunatas. Thi et al., (1999) reported that Setosphaeria sp. and C. rostrata were also found to effectively control Leptochloa chinensis without causing any damage to rice plant. However, scope of using mycoherbicides is also limited in controlling weeds in direct-seeded aerobic rice because such fungal pathogen requires flooded conditions. Moreover, biological control strategy is not something on which one can solely depend to control weeds especially in 
DSR where weed pressure is tremendous. Biological strategy should be used in conjunction with herbicides. However this is an interesting area of research where efforts can be made to develop biological control strategy which is compatible with other methods.

\begin{tabular}{|c|c|}
\hline Bioagent & Weeds \\
\hline \multicolumn{2}{|l|}{ Insect } \\
\hline Two beetles: Octotoma scabripennis and Uroplata giraldi & Lantana camara \\
\hline Scale insect Dactylopius tomentosus. & Prickly-pear weed - Opuntia \\
\hline Flea beetle Agasicles hygrophyla & Alligator weed - Alternanthera philoxeroides \\
\hline \multicolumn{2}{|l|}{ Fish } \\
\hline Common carp (Cyprimus carpio) Chinese carp & Aquatic weeds \\
\hline Mammals Manetee or sea-cow & Water hyacinth \\
\hline Snails Marisa sp and other fresh water snails & Submerged weeds like coontail and algae \\
\hline Fungi Rhizoctinia blight. & Hyacinth \\
\hline \multicolumn{2}{|l|}{ Mites } \\
\hline Tetranychus sp & Prickly pear \\
\hline Plants Cowpea as intercrop in sorghum & $\begin{array}{c}\text { Effectively reduces the growth of weeds in } \\
\text { sorghum }\end{array}$ \\
\hline
\end{tabular}

\section{Eradication}

Weed eradication is the complete removal of all live plant parts and seeds from an area. It is an expansive adventure since it costs more than that of the land. Besides complete elimination of all vegetation is not warranted as many of them are useful. Eradication of some noxious weeds such as Cuscuta and Lantana needed. Eradication should start when the weeds are small and limited in growth and spread.

\section{Integrated weed management}

Weed-rice ecological relationships are never static. The continuous adoption of any particular rice production practice causes a shift in dominance and distribution of rice weeds. In the formation of weed management programs, the type of rice culture, cultivars grown, tillage, crop establishment methods, planting geometry, fertilizer application and water management need to be systematically manipulated so as to create favourable conditions for crop growth, but unfavourable for weed survival. Manual and mechanical weeding in DSR should be used only in conjunction with other cultural and chemical methods to minimize labour requirements where appropriate.

None of the control measures in single can provide acceptable levels of weed control, and therefore, if various components are integrated in a logical sequence, considerable advances in weed management can be accomplished. Various agronomic tools have been evaluated for their potentiality in managing weeds (Liebman et al., 2001). But, all the agronomic tools may not work perfectly with every crop or weed species (Blackshaw et al., 2005). Integration of higher seed rate and spring- applied fertilizer in conjunction with limited herbicide use managed weeds efficiently and maintained high yields (Blackshaw et al., 2005). Adoption of IWM approach for sustainable rice production has been advocated by many researchers (Azmi and Baki 2002, Sunil et al., 2010, Jayadeva et al., 2011). Singh (2008) recorded that the sequential application of pre- emergence herbicides such as pendimethalin, in dry- seeded rice or early post-emergence application of anilofos/thiobencarb for the control of annual 
grasses in wet-seeded rice and postemergence application of 2,4-D against sedges and non-grassy weeds in wet and dryseeded rice may be a better option than the use of one herbicide. Some of the combinations or their sequential application may widen the weed control spectrum with better efficacy. Follow up application of 2, 4$D$ and Almix (a ready mixture of chlorimuron-methyl and metsulfuron-methyl) as post-emergence over preemergence application of pendimethalin in DSR provided effective control of annual grasses, broad-leaf weeds and annual sedges.

\section{Effect of different herbicides on yield and yield attributes}

Kumar et al., (2018) revealed that the application of pendimethalin followed by tank mixture of bispyribac and ethoxysulfuron resulted at par with weed free plots in respect of number of effective tillers, grain number and 1000-grain weight during all the years of experimentation (Table 3). Mean value of three years data reflected that tank mixture combination of bispyribac and ethoxysulfuron recorded similar rice grain and straw yield (4.4 and 5.3 tonnes/ha) to the plots kept weed free throughout the season (4.5 and 5.4 tonnes/ha), whereas weedy plots which received pendimethalin alone, produced least grain and straw yield (2.4 and 3.3 tonnes/ ha), respectively due to more weed biomass in the plots which affected the vegetative and reproductive phases of rice crop adversely. Further, pendimethalin followed by tank mixture application of bispyribac+ azimsulfuron produced higher grain and straw yield (4.0 and 5.0 tonnes/ ha) over rest of the treatments. Application of pendimethalin followed by fenoxaprop+ ethoxysulfuron produced similar grain yield, straw yield and other yield attributes as that of pendimethalin followed by bispyribac+ 2, 4-D. Application of pendimethalin followed by tank mixture of bispyribac and ethoxysulfuron produced $83 \%$ more grain yield than pendimethalin treated plots which were considered as weedy check. The reduction in yield due to weed infestation under DSR is reported up to $50-80 \%$ and it can be reached to $100 \%$ if weeds are not controlled throughout the season (Kumar et al., 2016).

Table.1 Major weed species in direct-seeded rice

\begin{tabular}{|c|c|c|c|}
\hline S.N. & Scientific Name & Common Name & Family \\
\hline \multicolumn{4}{|c|}{ A. Grasses: } \\
\hline 1. & Echinochloa colona & Wild rice & Poaceae \\
\hline 2. & Echinochloa crus-galli & Barnyard grass & Poaceae \\
\hline 3. & Eleusine indica & Goosegrass & Poaceae \\
\hline 4. & Leptochloa chinensis & Sprangletop & Poaceae \\
\hline 5. & Cynodon dactylon & Bermuda grass & Poaceae \\
\hline 6. & Dactylotenium aegyptium & Crow foot grass & Poaceae \\
\hline \multicolumn{4}{|c|}{ B. Broad-leaf weeds: } \\
\hline 1. & Digera arvensis & Digera kondra & Amarathaceae \\
\hline 2. & Ammania baccifera & Redstem & Lythraceae \\
\hline 3. & Cyanotis axillaris & Creeping cradle & Commelinaceae \\
\hline \multicolumn{4}{|c|}{ C. Sedges: } \\
\hline 1. & Cyperus difformis & umbrella sedge & Cyperaceae \\
\hline 2. & C. iria & Flat sedge & Cyperaceae \\
\hline 3. & C. rotundus & Purple nut sedge & Cyperaceae \\
\hline 4. & Fimbristylis miliacea & Tikog & Cyperaceae \\
\hline
\end{tabular}


Table.2 Commonly used herbicides in rice system

\begin{tabular}{|c|c|c|c|c|}
\hline S.N. & $\begin{array}{c}\text { Herbicide } \\
\text { (Trade name) }\end{array}$ & $\begin{array}{l}\text { Dose } \\
\text { (g/ha) }\end{array}$ & $\begin{array}{c}\text { Stages of } \\
\text { Application }\end{array}$ & Salient features \\
\hline \multicolumn{5}{|c|}{ Pre-emergence herbicide: } \\
\hline i. & $\begin{array}{l}\text { Pendimethalin } 30 \text { EC (Stomp, } \\
\text { Pendistar) }\end{array}$ & $1000-1500$ & 0-3 DAS & $\begin{array}{l}\text { Controls the annual grasses and some } \\
\text { broad leaf weeds. }\end{array}$ \\
\hline ii. & $\begin{array}{l}\text { Pretilachlor } 30.7 \% \text { EW } \\
\text { (Rifit, Erage-N) }\end{array}$ & $550-700$ & 0-3 DAS & $\begin{array}{l}\text { Require wet soil moisture for few days } \\
\text { for effective weed control }\end{array}$ \\
\hline iii. & $\begin{array}{l}\text { Anilofos 30EC } \\
\text { (Arozin, Aniloguard) }\end{array}$ & 400 & 3-5 DAS & $\begin{array}{l}\text { Control many annual grasses and some } \\
\text { BLWs. }\end{array}$ \\
\hline \multicolumn{5}{|c|}{ Post-emergence and mixture of herbicides: } \\
\hline i. & $\begin{array}{l}\text { Bispyribac-sodium 10SC (Nominee } \\
\text { gold, Adora) }\end{array}$ & 20 & 15-20 DAS & $\begin{array}{l}\text { Controls annual grasses and some } \\
\text { BLWs and sedges. }\end{array}$ \\
\hline ii. & $\begin{array}{l}\text { Chlorimuron-ethyl } \\
+ \text { Metsulfuronmethyl } 20 \text { WP (Almix) }\end{array}$ & 4 & 15-20 DAS & $\begin{array}{l}\text { Control broad spectrum of weeds } \\
\text { including annual BLWs and grasses. }\end{array}$ \\
\hline iii. & $\begin{array}{l}\text { Fenoxaprop-p-ethyl 6.7EC (Rice } \\
\text { Star) }\end{array}$ & $57-61$ & $25-30$ & $\begin{array}{l}\text { Excellent Control of annual grasses. } \\
\text { May be applied with all pre-emergence } \\
\text { herbicide }\end{array}$ \\
\hline iv. & Molinate + Bensulfuron & $\begin{array}{c}3.0+0.03 \mathrm{~kg} \\
\text { ai } / \mathrm{ha}\end{array}$ & 6-10 DAS & $\begin{array}{l}\text { Wide spectrum of weed control under } \\
\text { standing water conditions }\end{array}$ \\
\hline v. & Bispyribac-sodium 10SC + Almix & $20 \mathrm{~g}+4 \mathrm{~g}$ ai $/ \mathrm{ha}$ & 20 DAS & Kill all type of weed \\
\hline vi. & $\begin{array}{l}\text { Pretilachlor } 30.7 \% \mathrm{EW}+\text { Bispyribac- } \\
\text { sodium 10SC (Nominee gold, Adora) }\end{array}$ & $600+20$ & $\begin{array}{l}1-3 \text { and } 20 \\
\text { DAS }\end{array}$ & $\begin{array}{l}\text { Pre and post emergence herbicides. } \\
\text { which is give best result }\end{array}$ \\
\hline
\end{tabular}

Table.3 Effect of different post-emergence herbicide and tank mixture adaptation on yield and yield attributes (Pooled data of 2014- 16)

\begin{tabular}{|l|c|c|c|c|c|c|}
\hline Treatment & $\begin{array}{c}\text { Dose (g } \\
\text { a.i./ha) }\end{array}$ & $\begin{array}{c}\text { Effective } \\
\text { tillers/m }\end{array}$ & $\begin{array}{l}\text { Grains/ } \\
\text { panicle }\end{array}$ & $\begin{array}{c}\text { 1000- } \\
\text { Grain wt (g) }\end{array}$ & $\begin{array}{c}\text { Grain } \\
\text { yield } \\
\text { (t/ha) }\end{array}$ & $\begin{array}{c}\text { Stra } \\
\mathbf{w} \\
\text { yield } \\
\text { (t/ha) }\end{array}$ \\
\hline Weed free & - & 262 & 47 & 23.7 & 4.5 & 5.4 \\
\hline Pendimethalin alone & 1000 & 186 & 31 & 22.8 & 2.4 & 3.3 \\
\hline $\begin{array}{l}\text { Pendimethalin fb bispyribac } \\
\text { sodium }\end{array}$ & 25 & 230 & 41 & 23.0 & 3.6 & 4.7 \\
\hline $\begin{array}{l}\text { Pendimethalin fb bispyribac } \\
\text { + ethoxysulfuron }\end{array}$ & $25+35$ & 258 & 46 & 23.7 & 4.4 & 5.3 \\
\hline $\begin{array}{l}\text { Pendimethalin fb bispyribac } \\
\text { + azimsulfuron }\end{array}$ & $25+18$ & 247 & 43 & 23.4 & 4.0 & 5.0 \\
\hline $\begin{array}{l}\text { Pendimethalin fb bispyribac } \\
\text { + 2, 4-D sodium }\end{array}$ & $25+500$ & 240 & 41 & 23.2 & 3.8 & 4.8 \\
\hline Pendimethalin fb fenoxaprop & 90 & 235 & 40 & 23.1 & 3.6 & 4.7 \\
\hline $\begin{array}{l}\text { Pendimethalin fb fenoxaprop } \\
\text { + ethoxysulfuron }\end{array}$ & $90+35$ & 245 & 40 & 23.2 & 3.8 & 4.9 \\
\hline $\begin{array}{l}\text { Pendimethalin fb fenoxaprop } \\
\text { + azimsulfuron }\end{array}$ & $90+18$ & 223 & 38 & 22.9 & 3.4 & 4.5 \\
\hline SEm & & 2.0 & 0.6 & 0.27 & 0.05 & 0.06 \\
\hline CD(P=0.05) & & 5.8 & 1.79 & 0.80 & 0.14 & 0.18 \\
\hline
\end{tabular}


Table.4 Weeds density and weeds dry weight as influenced by different herbicide combinations in dry direct-seeded rice at 90 DAS (pooled data of 2 years)

\begin{tabular}{|c|c|c|c|c|c|c|c|c|}
\hline \multirow[t]{2}{*}{ Treatment } & \multicolumn{4}{|c|}{ Weed density (no./m2) } & \multicolumn{4}{|c|}{ Weed dry weight $(\mathrm{g} / \mathrm{m} 2)$} \\
\hline & Sedges & Grasses & Broad-leaf & Total & Sedges & Grasses & $\begin{array}{l}\text { Broad- } \\
\text { leaf }\end{array}$ & Total \\
\hline $\begin{array}{l}\text { Bensulfuron-methyl + pretilachlor } \\
\text { fb triafamone + ethoxysulfurn }\end{array}$ & $\begin{array}{l}2.58 \\
(57)\end{array}$ & $\begin{array}{c}1.13 \\
(11.7)\end{array}$ & $\begin{array}{c}1.28 \\
(17.0)\end{array}$ & $\begin{array}{c}1.56 \\
(34.3)\end{array}$ & $\begin{array}{l}1.45 \\
(1.1)\end{array}$ & $\begin{array}{l}1.74 \\
(2.0)\end{array}$ & $\begin{array}{l}2.02 \\
(3.1)\end{array}$ & $\begin{array}{l}0.91 \\
(6.2)\end{array}$ \\
\hline $\begin{array}{l}\text { Oxadiargyl fb triafamone }+ \\
\text { ethoxysulfuron }\end{array}$ & $\begin{array}{c}4.08 \\
(15.7)\end{array}$ & $\begin{array}{c}1.50 \\
(30.0)\end{array}$ & $\begin{array}{c}1.73 \\
(52.0)\end{array}$ & $\begin{array}{c}2.00 \\
(97.7)\end{array}$ & $\begin{array}{l}1.99 \\
(3.0)\end{array}$ & $\begin{array}{l}2.53 \\
(5.4)\end{array}$ & $\begin{array}{l}3.21 \\
(9.3)\end{array}$ & $\begin{array}{c}1.29 \\
(17.7)\end{array}$ \\
\hline $\begin{array}{l}\text { Pendimetalin fb triafamone + } \\
\text { ethoxysulfuron }\end{array}$ & $\begin{array}{c}4.24 \\
(17.0)\end{array}$ & $\begin{array}{c}1.65 \\
(42.3)\end{array}$ & $\begin{array}{c}1.93 \\
(83.7)\end{array}$ & $\begin{array}{l}2.16 \\
(143)\end{array}$ & $\begin{array}{l}2.05 \\
(3.2)\end{array}$ & $\begin{array}{l}2.95 \\
(7.7)\end{array}$ & $\begin{array}{c}4.02 \\
(15.2)\end{array}$ & $\begin{array}{l}1.45 \\
(26.1)\end{array}$ \\
\hline $\begin{array}{l}\text { Pyrazosulfuron-ethyl fb } \\
\text { triafamone + ethoxysulfuron }\end{array}$ & $\begin{array}{c}4.00 \\
(15.0)\end{array}$ & $\begin{array}{c}1.62 \\
(40.0)\end{array}$ & $\begin{array}{c}1.79 \\
(60.0)\end{array}$ & $\begin{array}{c}2.07 \\
(115.0)\end{array}$ & $\begin{array}{l}1.96 \\
(2.9)\end{array}$ & $\begin{array}{l}2.86 \\
(7.2)\end{array}$ & $\begin{array}{c}3.42 \\
(10.7)\end{array}$ & $\begin{array}{l}1.36 \\
(20.7)\end{array}$ \\
\hline $\begin{array}{l}\text { Bensulfuron-methyl + pretilachlor } \\
\text { fb bispyribac-sodium }\end{array}$ & $\begin{array}{l}2.45 \\
(5.0)\end{array}$ & $\begin{array}{c}1.10 \\
(10.7)\end{array}$ & $\begin{array}{c}1.24 \\
(15.7)\end{array}$ & $\begin{array}{c}1.52 \\
(31.3)\end{array}$ & $\begin{array}{l}1.40 \\
(1.0)\end{array}$ & $\begin{array}{l}1.70 \\
(1.9)\end{array}$ & $\begin{array}{l}1.97 \\
(2.9)\end{array}$ & $\begin{array}{l}0.89 \\
(5.8)\end{array}$ \\
\hline Oxadiargyl fb bispyribac-sodium & $\begin{array}{c}3.41 \\
(10.7)\end{array}$ & $\begin{array}{c}1.42 \\
(25.0)\end{array}$ & $\begin{array}{c}1.62 \\
(39.7)\end{array}$ & $\begin{array}{c}1.89 \\
(75.3)\end{array}$ & $\begin{array}{l}1.74 \\
(2.0)\end{array}$ & $\begin{array}{l}2.30 \\
(4.3)\end{array}$ & $\begin{array}{l}2.90 \\
(7.5)\end{array}$ & $\begin{array}{c}1.20 \\
(13.8)\end{array}$ \\
\hline $\begin{array}{l}\text { Pendimethalin }(38.7 \% \text { CS) fb } \\
\text { bispyribac-sodium }\end{array}$ & $\begin{array}{c}3.70 \\
(12.7)\end{array}$ & $\begin{array}{c}1.47 \\
(27.7)\end{array}$ & $\begin{array}{c}1.69 \\
(47.7)\end{array}$ & $\begin{array}{l}1.95 \\
(88.0)\end{array}$ & $\begin{array}{l}1.85 \\
(2.4)\end{array}$ & $\begin{array}{l}2.43 \\
(4.9)\end{array}$ & $\begin{array}{l}3.13 \\
(8.8)\end{array}$ & $\begin{array}{c}1.26 \\
(16.2)\end{array}$ \\
\hline $\begin{array}{l}\text { Pyrazosulfuron-ethyl fb } \\
\text { bispyribac- sodium }\end{array}$ & $\begin{array}{c}3.36 \\
(10.3)\end{array}$ & $\begin{array}{c}1.37 \\
(21.7)\end{array}$ & $\begin{array}{c}1.62 \\
(39.7)\end{array}$ & $\begin{array}{c}1.87 \\
(71.7)\end{array}$ & $\begin{array}{l}1.73 \\
(2.0)\end{array}$ & $\begin{array}{l}2.20 \\
(3.9)\end{array}$ & $\begin{array}{l}2.88 \\
(7.3)\end{array}$ & $\begin{array}{c}1.18 \\
(13.2)\end{array}$ \\
\hline $\begin{array}{l}\text { Pendimethalin ( } 38.7 \% \text { CS) fb } \\
\text { penoxsulam + cyhalofop-butyl }\end{array}$ & $\begin{array}{c}4.47 \\
(19.0)\end{array}$ & $\begin{array}{c}1.63 \\
(41.0) \\
\end{array}$ & $\begin{array}{c}1.93 \\
(84.7)\end{array}$ & $\begin{array}{c}2.16 \\
(144.7)\end{array}$ & $\begin{array}{l}2.19 \\
(3.8)\end{array}$ & $\begin{array}{l}2.92 \\
(7.5)\end{array}$ & $\begin{array}{c}4.05 \\
(15.4)\end{array}$ & $\begin{array}{c}1.46 \\
(26.7)\end{array}$ \\
\hline Three mechanical weedings & $\begin{array}{c}4.20 \\
(16.7)\end{array}$ & $\begin{array}{c}1.61 \\
(38.7)\end{array}$ & $\begin{array}{c}1.89 \\
(76.0)\end{array}$ & $\begin{array}{c}2.12 \\
(131.3)\end{array}$ & $\begin{array}{l}2.05 \\
(3.2)\end{array}$ & $\begin{array}{l}2.81 \\
(6.9)\end{array}$ & $\begin{array}{c}3.85 \\
(13.8)\end{array}$ & $\begin{array}{c}1.41 \\
(23.9)\end{array}$ \\
\hline Hand weedings & $\begin{array}{l}2.38 \\
(4.7)\end{array}$ & $\begin{array}{l}1.05 \\
(9.3)\end{array}$ & $\begin{array}{c}1.22 \\
(14.7)\end{array}$ & $\begin{array}{c}1.49 \\
(28.7)\end{array}$ & $\begin{array}{l}1.38 \\
(0.9)\end{array}$ & $\begin{array}{l}1.64 \\
(1.7)\end{array}$ & $\begin{array}{l}1.92 \\
(2.7)\end{array}$ & $\begin{array}{l}0.86 \\
(5.3)\end{array}$ \\
\hline Weedy check & $\begin{array}{c}4.54 \\
(19.7)\end{array}$ & $\begin{array}{c}1.77 \\
(56.3)\end{array}$ & $\begin{array}{c}2.12 \\
(128.5)\end{array}$ & $\begin{array}{c}2.31 \\
(204.5)\end{array}$ & $\begin{array}{l}2.43 \\
(4.9)\end{array}$ & $\begin{array}{c}3.58 \\
(11.9)\end{array}$ & $\begin{array}{c}4.96 \\
(23.7)\end{array}$ & $\begin{array}{c}1.63 \\
(40.5)\end{array}$ \\
\hline $\operatorname{LSD}(p=0.05)$ & 0.33 & 0.14 & 0.15 & 0.21 & 0.21 & 0.24 & 0.31 & 0.16 \\
\hline
\end{tabular}

Fig. 1: Performance of different rice establishment method in Odisha (2017-2018)

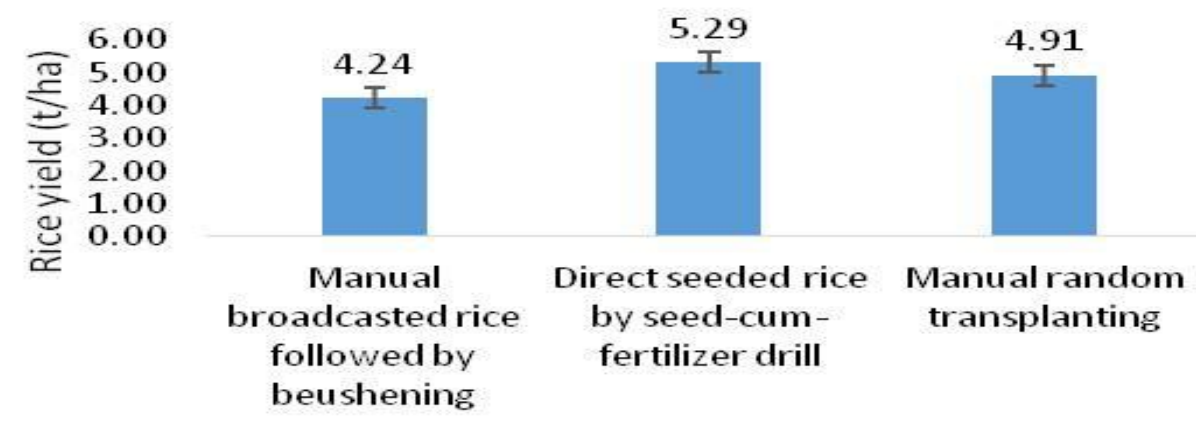

Rice establishment method 


\section{Weed density and dry weight}

Nagarjun et al., (2019) studies that among the different category of weeds, in unweeded control the density and dry weight of broadleaf weeds $\left(128.5 / \mathrm{m}^{2}\right.$ and $23.7 \mathrm{~g} / \mathrm{m}^{2}$, respectively) was higher followed by grasses $\left(56.3 / \mathrm{m}^{2}\right.$ and $11.9 \mathrm{~g} / \mathrm{m}^{2}$, respectively) and sedges $\left(56.3 / \mathrm{m}^{2}\right.$ and $4.9 \mathrm{~g} / \mathrm{m}^{2}$, respectively) at 90 DAS (Table 4). Effective control of weeds was noticed at 90 DAS with application of bensulfuron-methyl + pretilachlor $(60+600$ $\mathrm{g} / \mathrm{ha}$ ) as pre-emergence $\mathrm{fb}$ bispyribac- sodium ( $25 \mathrm{~g} / \mathrm{ha}$ ) at 25 DAS followed by bensulfuronmethyl + pretilachlor $(60+600 \mathrm{~g} / \mathrm{ha})$ as preemergence fb triafamone + ethoxysulfurn $(60$ $\mathrm{g} / \mathrm{ha}$ at $25 \mathrm{DAS}$ ) as evident from the reduced weed density and dry weight due to broader spectrum of effective herbicides on major weed flora apart from hand weeding. All these herbicide mixtures were superior to weedy control in reducing the weeds' density and dry weight. The results were in conformity with the results obtained by Kumaran et al., 2015.

In conclusion the direct-seeded rice is catching interest of researchers, planners and farmers in India. Various herbicide options are available to control weeds economically in dry-seeded aerobic rice systems. Chemical control is the smartest and most economic option for weed management in present day agriculture. Tank mixture herbicides are provided effective control on diverse weed population under DSR and may be recommended to the farmers who are adopting DSR technique.

\section{References}

AICRP-WC.2002-03 Annual Report, All India Coordinated Research Project on Weed Control. NRC for weed science, Jabalpur, India $47 \mathrm{p}$.

Anwar MP, Juraimi AS, Puteh A, Selamat A,
Man A and Hakim MA. 2011. Seeding method and rate influence on weed suppression in aerobic rice. African Journal of Biotechnology 10(68): 15259-15271.

Awan TH, Ali I, Manzoor Z, Safdar I and Ashraf M. 2006. Economic effect of different plant establishment techniques on rice production. Journal of Agricultural Research 9: 580-588.

Bhatia A, Ghosh A, Kumar V, Tomer R, Singh SD and Pathak H. 2011. Effect of elevated tropospheric ozone on methane and nitrous oxide emission from rice soil in north India. Agriculture, Ecosystems \& Environment 144: 21-28.

Buhler DD (2002). Challenges and opportunities for integrated weed management. Weed Sci., 50:273- 280.

Chauhan BS (2012). Weed management in direct seeded rice systems. Los Baños (Philippines): International Rice Research Institute. 20p.

Chauhan BS and Johnson DE. 2010. The role of seed ecology in improving weed management strategies in the tropics. Advances in Agronomy 105: 221-262.

Dhyani VC, Singh VP, Singh SP, Kumar A, Johnson ED and Mortimer M. 2010. Population and dry matter dynamics of Echinochloa colona as influenced by rice (Oryza sativa) establishment techniques. XIX National Symposium on "Resource management Approaches towards Livelihood Security" held at University of Agriculture Sciences, Bengaluru, Karnataka, December 2-4.

Farooq M, Basra SMA, Ahmad N and Murtaza G. 2009. Enhancing the performance of transplanted coarse rice by seed priming. Paddy and Water Environment 7: 55-63.

Gianessi L, Williams A. 2011. Herbicides Are Key for the Sustainability of Rice Growing in South Asia. International Pesticide Benefits Case Study No 7. 
Gibson KD and Fischer AJ. 2004. Competitiveness of rice cultivars as a tool for crop-based weed management, pp. 517-537. In: Weed Biology and Management (Ed. Inderjit) Kulwer Academic Publishers, the Netherlands.

Gibson KD, Hil JE, Foin TC, Caton BP and Fischer AJ. 2001. Water seeded rice cultivars differ in ability to interfere with water grass. Agronomy Journal 93: 326-332.

Grichar WJ, Bessler BA and Brewer KD. 2004 Effect of row spacing and herbicide dose on weed control and grain sorghum yield. Crop Protection 23: 263-267.

Ho NK and Itoh K. 1991. Changes in weed flora and their distribution in the Muda area. 8th MADA/TARC Quarterly Meeting, 3 November 1991, Alor Setar, Malaysia.

Jayadeva HM, Bhairappanavar ST, Hugar AY, Rangaswamy BR, Mallikarjun GB, Malleshappa C and Naik DC. 2011. Integrated weed management in aerobic rice (Oryza sativa L.). Agricultural Science Digest 31(1): 58-61.

Juraimi AS, Saiful AHM, Uddin MK, Anwar MP and Azmi M. 2013. Sustainable weed management in direct seeded rice culture: A review. Aust. J. Crop Sci., 7(7):989-1002.

Kumar S, Shivani and Bhatt B P. 2016. Management of complex weed flora under direct seeded rice. Indian Farming 111: 297-413.

Kumar S. Shivani Mishra J S, Kumar S, Kumar U and Bharati R C. 2018. Efficacy of pre- and post-emergence herbicides on complex weed flora in direct-seeded rice (Oryza sativa) in the eastern plains. Indian Journal of Agricultural Sciences 88 (3): 387-92.

Kumaran ST, Kathiseran P, Muraliarthanari C, Chinnusamy and Sanjivkumar V. 2015. Efficacy of new herbicide (byspyribac sodium 10\% SC) against different weed flora, nutrient uptake in rice and their residual effects on succeeding crop of green gram under Zero tillage. Journal of Applied Natural Science 7(1): 279-285.

Mahajan G, Ramesha MS and Rupinder-Kaur. 2011. Screening for weed competitiveness in rice - way to sustainable rice production in the face of global climate change. Proceedings of International Conference on Preparing Agriculture for Climate Change, Ludhiana, Feb 6-8, 2011.

Mai V, Chien HV, Suong VTT and Thiet LV. 1998. Survey and analysis of farmers' seed contamination by weed and weedy rice seeds in South Vietnam. International Symposium on Wild and Weedy Rices in Agroecosystems. 10-11 August 1998, Ho chi Minh City, Vietnam.

Mortimer M and Johnson DE. 2008. Weed species shifts in response to direct seeding in rice. P0. 19. In: Direct Seeding of Rice and Weed Management in the Irrigated Rice-Wheat Cropping System of the Indo- Gangetic Plains, International Rice Research Institute, Los Banos, Philippines and Directorate of Experiment Station, G.B. Pant University of Agriculture and Technology, Pantnagar, India.

Nagarjun P, Dhanapal GN, Sanjay MT, Yogananda SB and Muthuraju R. 2019. Energy budgeting and economics of weed management in dry direct-seeded rice. Indian Journal of Weed Science 51(1): $1-5$

Ottis BV, Smith KL, Scott RC and Talbert RE. 2005. Rice yield and quality as affected by cultivar and red rice (Oryza sativa) density. Weed Science 53: 499504.

Rahman MM and Masood M. 2012. Aerobic System: potential water saving Boro 
rice production technology. Adaptation of aerobic system for boro rice cultivation in farmer's field for saving irrigation water and attaining food security-Project P: 1-2.

Rana MN, Al Mamum MA, Zahan A, Ahmed MN and Mridha MAJ. 2014. Effect of planting methods on the yield and yield attributes of short duration Aman rice. American Journal of Plant Science 5: $25-255$.

Rao AN, Johnson DE, Sivaprasad B, Ladha JK and Mortimer AM .2007. Weed management in direct seeded rice. Advances in Agronomy 93: 153-255.

Singh D. 2010. Studies to Moderate the Heat Stress Effects on Wheat (Triticum aestivum L.) Productivity. M.Sc. Thesis, Punjab Agricultural University, Ludhiana, Punjab, India.

Singh G, Singh OP, Kumar V and Kumar T. 2008. Effect of methods of establishment and tillage practices on the productivity of rice (Oryza sativa) wheat (Triticum astivum) cropping system. Indian Journal of Agricultural Sciences 78: 163-166.

Singh S, Singh G, Singh VP and Singh AP. 2005. Effect of establishment methods and weed management practices on weeds and rice in rice-wheat system. Indian Journal of Weed Science 37(1\&2): 51-57.

Singh VP, Singh G, Singh RK, Kumar A, Dhyani VC, Singh SP and Singh MK. 2006. Direct seeded rice and zero tillage weed: A boom for farmers. Indian
Farmer's Digest.

Singh VP, Singh SP, Dhyani VC, Tripathi N, Banga A and Yadav VR. 2013. Effect of establishment methods on shifting of weed flora in rice-wheat cropping system. 24th Asian-Pacific Weed Science Society Conference, October 22-25, 2013, Bandung, Indonesia.

Sunil CM, Shekara BG, Kalyanmurthy KN and Shankaralingapa BC .2010. Growth and yield of aerobic rice as influenced by integrated weed management practices. Indian Journal of Weed Science 42(3\&4): 180-183.

Thi HL, Man LH, Chin DV, Auld BA, Hetherington SD. 1999. Research on some fungi to control barnyard grass and red sprangle top in rice. In Proceedings of the 17th Asian-pacific Weed Science Society conference, Bangkok, Thailand. pp. 562-566.

Tuong TP, Pablico PP, Yamauchi M, Confesor R, Moody K. 2000. Increasing water productivity and weed suppression of wet seeded rice: effect of water management and rice genotypes. Journal of Experimental Agriculture 36: $1-19$

Walia US. 2006. Weed Management. New Delhi: Kalyani Publishers.

Weiner J, Griepentrog HW and Kristensen L. 2001. Suppression of weeds by spring wheat Triticum aestivum increases with crop density and spatial uniformity. $J$. Appl. Ecol. 38, 784e790.

\section{How to cite this article:}

Pradeep Rajput, Adesh Singh, Ravindra Kumar Rajput, Gaurav Shukla and Pravesh Kumar 2020. Effect of Pre and Post Emergence Herbicides on Weeds and Productivity of Aerobic Basmati Rice (Oryza Sativa L): A Review. Int.J.Curr.Microbiol.App.Sci. 9(12): 2085-2097. doi: https://doi.org/10.20546/ijcmas.2020.912.245 